\title{
PROBLEMATYKA SUMIENIA W WYBRANYCH PUBLIKACJACH KS. PROF. STANISŁAWA OLEJNIKA
}

Temat sumienia należy do fundamentalnych zagadnień etyki i teologii moralnej. Dlatego w jakimś wymiarze jest on przedmiotem refleksji każdego teologa moralisty. Tak było również w przypadku ks. profesora Stanisława Olejnika. Przy różnych okazjach podkreślano znaczenie jego dorobku naukowego, jednak oceny te, ze względu na swój ogólny charakter, nie skupiały się na problematyce sumienia ${ }^{1}$. Przypomnienie dokonań na tym polu ma obecnie wymiar nie tylko teoretyczny, jako przyczynek do historii polskiej teologii moralnej ${ }^{2}$,

1 Por. T. R e ro ń, Drogi chrześcijańskiej moralności. Wkład ks. prof. Stanisława Olejnika w odnowę teologii moralnej, „Wrocławski Przegląd Teologiczny”, 15(2007) nr 2, s. 87-100; M. G r a c z y k, Ksiądz profesor Stanisław Olejnik jako teolog, „Studia Włocławskie”, 3(2000), s. 7-19; P. G ó r a 1 c z y k, W służbie prawdzie i miłości. Ksiądz Profesor Stanisław Olejnik - teolog moralista, w: P. G ó r a 1 c z y k, J.A. S o b k o w i a k (red.), Przemoc i terror. Książka dedykowana Księdzu Profesorowi Stanisławowi Olejnikowi w 80ta rocznicę urodzin i 50ta rocznice pracy naukowej, Warszawa 2001, s. 20-29; Tenże, Misja uczonego-ksiądz profesor Stanisław Olejnik, w: J. B a g r o w i c z (red.), W służbie Kościołowi i nauce. Księga jubileuszowa dedykowana Księdzu Profesorowi Stanisławowi Olejnikowi, Włocławek 1994, s. 20-27.

2 Publikacje ukazujące historię polskiej teologii moralnej XX wieku-ze względu na syntetyczny charakter - choć wskazują na dokonania ks. prof. Olejnika, to temat sumienia w jego twórczości jedynie sygnalizują lub podejmują go aspektowo. Por. J. K o p c iń s k i, Polska teologia moralna XX wieku, Kraków 2000, s. 168-185, 
ale nade wszystko wymiar praktyczny, uzasadniony współczesnymi problemami i dylematami etycznymi. W dyskusji nad nimi bardzo często pojawia się kategoria sumienia, na którą zgodnie powołują się adwersarze, proponując jednak skrajnie różne rozwiązania konkretnej kwestii moralnej. W ten sposób pojęcie sumienia powszechnie przywoływane, ale różnie interpretowane, samo staje się ważnym elementem współczesnej debaty etycznej, dotyczącej m.in. problemów bioetycznych. Powrót do twórczości ks. profesora Olejnika może tę debatę uporządkować i wzbogacić. W tym celu warto przypomnieć jego wypowiedzi na temat sumienia, które pojawiły się w ramach prezentacji innych zagadnień, omówić ujecie sumienia obecne w podręczniku teologii moralnej oraz w refleksji nad kwestiami etyki lekarskiej.

\section{SUMIENIE JAKO PRZEDMIOT PERMANENTNEJ REFLEKSJI TEOLOGICZNOMORALNEJ}

Zagadnienie sumienia obecne jest już w pierwszych publikacjach naukowych ks. prof. Olejnika ${ }^{3}$. W artykule poświęconym odpowiedzialności moralnej zwraca uwagę na konieczność szerszego spojrzenia na człowieka jako podmiot tej odpowiedzialności, uwzględniając zdobycze biologii, psychologii i socjologii, a nawet genetyki, kryminologii i psychopatologii. Nie chodzi przy tym

194, 199, 215, 225, 234-235, 243, 248-249; M. Ni e d ź w i e c k i, Odnowa i rozwój polskiej teologii moralnej po Soborze Watykańskim II, Kraków 2002, s. 143-145; F. Gr e n i u k, Katolicka teologia moralna w poszukiwaniu własnej tożsamości, Lublin 1993, s. 13, 28, 61-62, 202; Tenże, Dzieje ksztattowania się koncepcji sumienia, w: J. N a g ó r n y, A. D e r d z i u k (red.), Człowiek-Sumienie-Wartości. Materiały z sympozjum KUL, 2-3 XII 1996 r., Lublin 1997, s. 87; Z. W a n a t, Sumienie w blasku Prawdy. Polska teologia sumienia XX wieku, Toruń 2012, s. 100-104; B. I n l e n d e r, Problematyka sumienia $w$ publikacjach polskich, „Collectanea Theologica", 60(1990) nr 3, s. 137-138; J. W i c h r o w i c z, Określenia sumienia w ostatnich publikacjach, „Collectanea Theologica”, 52(1982) f. 2, s. 117-118.

3 Por. I. W e r b i ń s k i, Spis publikacji naukowych ks. prof. dra hab. Stanistawa Olejnika, w: J. B a g r o w i c z (red.), W służbie Kościołowi i nauce, dz. cyt., s. 34. 
o jakieś relatywizowanie moralności chrześcijańskiej, która zawsze odwoływała się do obiektywnych i niezmiennych norm, ale o dostrzeżenie wyjątkowości każdego człowieka, którego sumienie może być bardzo różnie ukształtowane ${ }^{4}$. Dlatego podkreślając potrzebę dowartościowania tego subiektywnego aspektu ks. Olejnik stwierdza, że „właśnie sumienie człowieka, urabiane wedle obiektywnego prawa moralnego, jest najbliższą i jedynie obowiązującą normą postępowania; jest funkcją całej osobowości człowieka, wyrazem dyspozycji wrodzonych i nabytych jednostki, a w pewnym stopniu także poglądów etycznych i poziomu moralnego środowiska, w jakim dana jednostka przebywała i przebywa. Podmiotem moralności nie jest abstrakcyjna natura ludzka, ale dany człowiek, ta i ta osoba, w tym a tym wieku, o takim i takim wykształceniu, postawiona $\mathrm{w}$ takich i takich warunkach życiowych"s.

Kolejny artykuł został w całości poświęcony tematowi sumienia. Stanowi on zapowiedź szerokiego, integralnego ujęcia, które później zostanie zaprezentowane w podręczniku do teologii moralnej. Ks. Profesor w sposób zwięzły zwraca uwagę na wieloznaczność pojęcia sumienia, na powszechność opisów tego zjawiska w literaturze starożytnej i w Biblii, na spekulatywną refleksję średniowiecznych teologów (Aleksander z Hales, św. Tomasz, św. Bonawentura) oraz na określenie sumienia przez św. Alfonsa Liguori. Podkreśla potrzebę odwołania się do badań nad sumieniem przy pomocy metody fenemenologicznej, do współczesnej psychologii i etyki wartości, wskazując m.in. na Husserla, Schelera, Hartmanna i von Hildebranda. Dzięki nim bowiem słusznie dowartościowana została rola sfery pożądawczo-afektywnej, uzupełniając wcześniejszą jednostronnie intelektualistyczną teorię sumienia ${ }^{6}$. Dlatego podsumowując stwierdza, że „sumienie to nie tylko sąd, logiczny wniosek praktyczny, ale przeżycie obejmujące całość osoby ludzkiej. Fenomenologia sumienia

4 Por. S. Olej n i k, Z problematyki odpowiedzialności moralnej, „Ateneum Kapłańskie”, 50(1949) z. 3, s. 260-261.

5 Tamże, s. 261.

6 Por. S. O l e j n i k, Sumienie, „Ateneum Kapłańskie”, 51(1949) z. 4, s. 363-369. 
przekonywa nas o tym wyraźnie, ujawniając i wyjaśniając wielopłaszczyznowość funkcji sumienia". Potwierdza to zarówno przeżywanie pewnego konfliktu i walki związanej z koniecznością rozstrzygnięć etycznych przed podjęciem działania, jak i uczucia towarzyszące ocenie moralnej już dokonanego czynu (wyrzuty sumienia, nagana, smutek i żal, albo przeciwnie, spokój, zadowolenie i radość dobrego sumienia). „Ważna jest cała treść przeżycia, nie tylko jego element świadomościowy. A treść ta jest wielopłaszczyznowa i skomplikowana, sięga aż do głębi psychicznej indywidualności człowieka"7.

Temu szerokiemu spojrzeniu na zagadnienie sumienia towarzyszy świadomość dokonań współczesnych polskich moralistów. Dokonując przeglądu ich dorobku z okazji 50-lecia istnienia „Ateneum Kapłańskiego" (lata 1909-1959) wymienia główne aspekty badawcze obecne w publikacjach. Zwraca uwagę na zjawiskową stronę sumienia, którą przedstawiali J. Bączek, J. Jakubczyk i L. Rudnicki; na powszechność tego zjawiska jako wyraz przyrodzonego porządku moralnego omawianą przez A. Szymańskiego i L. Halbana; na podkreślany przez J. Bilczewskiego wewnętrzny charakter sumienia jako osobistej normy działania oraz na sprawę jego wykrzywień oraz perspektyw wychowawczych, o czym szerzej pisał A. L. Szafrański. Ks. Olejnik sklasyfikował i krótko omówił także wydane w tym okresie podręczniki etyki katolickiej zwracając uwagę na obecną w nich problematykę sumienia ${ }^{8}$.

Jednym z przykładów odwoływania się do magisterium Kościoła nt. sumienia jest refleksja nad encykliką św. Jana Pawła II Veritatis splendor. W jej świetle ks. Olejnik zwraca uwagę na niebezpieczeństwo skrajnego subiektywizmu i anarchii na płaszczyźnie etycznej wynikających z odrzucenia obiektywnego charakteru prawdy moralnej. Bez jej prymatu sumienie traci pewny punkt odniesienia i uzasadnienie swojej normatywnej roli. Dlatego - służąc

7 Tamże, s. 370-371.

8 Por. S. Olej n i k, Ostatnie pótwiecze katolickiej myśli etycznej w Polsce, „Ateneum Kapłańskie” 58(1959) z. 1-3, s. 108-109, 121. 
ludzkim sumieniom - Kościół przepowiada i broni prawdy moralnej9. Ks. Profesor krytykuje także współczesne tendencje ograniczające rolę teologów moralistów do formułowania jedynie ogólnych zasad postępowania, by rzekomo z zewnątrz nie narzucać rozstrzygnięć indywidualnemu sumieniu ludzi, lecz szanować wolność ich decyzji. Podkreśla, że wierni potrzebują nie tyle ogólnych wskazań, ile raczej szczegółowych, kategorialnych ocen i norm działania. „Teologowie zaś wyjaśniając i uzasadniając bardziej szczegółowe, ale obiektywne prawdy moralne, nie łamią wolności sumienia, lecz wspomagają je, chroniąc przed błędnymi, często bardzo szkodliwymi decyzjami"10.

\section{TEMAT SUMIENIA W KONTEKŚCIE INNYCH ZAGADNIEŃ ETYCZNYCH}

Ze względu na swoje podstawowe znaczenie dla życia moralnego temat sumienia pojawia się przy okazji omawiania innych zagadnień. Przykładem tego jest refleksja nad ostatecznym kryterium dobra w moralności chrześcijańskiej. Ks. Olejnik podejmuje ją w potrójnej perspektywie: nomologicznej (kryterium zgodności działania z wolą Bożą), teleologicznej (kryterium zgodności działania z ostatecznym celem życia człowieka) oraz chrystologicznej (kryterium zgodności działania z nauczaniem i postępowaniem Jezusa Chrystusa). Na rolę sumienia wskazuje najpierw ukazując wolę Bożą jako kryterium dobra moralnego. Jej wyrazem jest m.in. objawione prawo moralne, które obowiązuje wszystkich, ale także rady ewangeliczne, którą są jedną z możliwych dróg do osiągnięcia doskonałości. W odniesieniu do konkretnego człowieka, który ma zrealizować to powszechne

9 Por. S. O l e j n i k, Veritatis splendor-encyklika Jana Pawła II o podstawach moralności chrześcijańskiej, „Ateneum Kapłańskie”, 122(1994) z. 2, s. 339-342.

10 S. Ole j n i k, Encyklika Veritatis splendor o misji i postudze teologów moralistów w Kościele, w: E. J a n i a k (red.), W prawdzie ku wolności. W kręgu encykliki Veritatis splendor, Wrocław 1994, s. 203-204. 
powołanie do doskonałości (por. Mt 5, 48), „drogi te określa i wyznacza Bóg w religijnym dialogu, poprzez głos i nakaz sumienia"11.

Następnie rola sumienia wspomniana została w perspektywie teleologicznej, w której świadome i dobrowolne działanie człowieka jest moralnie dobre wtedy, gdy przybliża go do ostatecznego celu ziemskiego życia. Tego rodzaju osobiste przekonanie musi towarzyszyć podejmowanym działaniom. „Czyn ludzki nie może być uznany za moralnie dobry w pełnym rozumieniu moralności, jeśli nie jest zgodny z osobistym przekonaniem jego sprawcy, z jego rozeznaniem dobra, czyli z jego sumieniem. Koniecznym warunkiem i współczynnikiem realizacji dobra w pełni ludzkiego jest osobiste przeświadczenie tego, kto działa, że działa moralnie dobrze. Jeśli tego nie ma, działanie, nawet skądinąd dobre, musi być uznane za złe. «Wszystko bowiem, co się czyni niezgodnie z przekonaniem, jest grzechem» (Rz 14, 23)"'12. Natomiast wskazując na osobę Jezusa Chrystusa, która dla chrześcijanina stanowi nie tylko wzór do naśladowania, ale także źródło nowego życia, a więc w perspektywie chrystologicznej, ks. Profesor nie wspomina nic o roli sumienia. Wyraźnie podkreśla konieczność łaski Ducha Świętego, by konkretne działania były wyrazem nadprzyrodzonej miłości jako miary moralnego dobra, ale nie odnosi jej wprost do etapu decyzji i wyborów moralnych dokonywanych dzięki osądowi sumienia ${ }^{13}$.

Inną okazją do wskazania na istotę i znaczenie sumienia był tekst poświęcony humanistycznym aspektom etyki katolickiej w kontekście dialogu ekumenicznego, międzyreligijnego i z ludźmi niewierzącymi. Dialog taki domaga się odnalezienia wspólnej ogólnoludzkiej płaszczyzny (humanum), na której będzie możliwe spotkanie i zgoda w odniesieniu do zasad życia moralnego. W duchu poszukiwania tego, co łączy ks. Olejnik proponuje spokojne spojrzenie na doktrynę

11 S. O le j n i k, Problem ostatecznego kryterium dobra $w$ moralności chrześcijańskiej, w: B. Bejze (red.), O Bogu i o człowieku, t. 2: Problemy filozoficzne i teologiczne, Warszawa 1969, s. 182.

12 Tamże, s. 186.

13 Por. tamże, s. 187-190. 
Kościoła, której ateiści odmawiali znamion humanistycznych, przyznając prawo do reprezentowania humanizmu wyłącznie nurtom areligijnym. Wśród zarzutów stawianych Kościołowi jest rzekome zagrożenie praw i wolności ludzkiego sumienia poprzez odwoływanie się do prawa Bożego i jego pierwszorzędnej roli w określaniu porządku moralnego. Podstawą formułowania takich zarzutów jest koncepcja sumienia, które traktowane jest nie tylko jako autentyczny wyraz godności człowieka, ale nade wszystko jako jedynie miarodajna i ostateczna instancja oceny moralnej ludzkiego działania ${ }^{14}$.

Odpowiadając na powyższy zarzut, ks. Profesor zwraca najpierw uwagę, że obrona suwerennych praw sumienia, która dotyczy konieczności kierowania się zdrowym osądem moralnym, tzn. osądem rozumnym, obiektywnym i odpowiedzialnym, liczącym się z wymaganiami rozumnej natury ludzkiej, nie stoi w sprzeczności z nauczaniem Kościoła. On także traktuje sumienie jako miarodajną i wiążącą normę postępowania, dostrzegając w nim ponadto głos Boży i wyraz ponadludzkiego prawa. Natomiast istotna różnica w rozumieniu sumienia dotyczy kwestii jego omylności oraz potrzeby obiektywnego punktu odniesienia dla jego prawidłowego uformowania. Owszem, należy postępować zgodnie z własnym sumieniem, ale „nie jest to jednak norma ostateczna, absolutnie pewna i miarodajna. Ponieważ w tej instancji oceny nie jest wykluczony błąd, stąd usprawiedliwiony wydaje się postulat kontroli. Etyka katolicka zobowiązuje do kontrolowania i ewentualnego korygowania sądu sumienia, oczywiście tylko w sytuacjach, w których możliwość błędu tego sądu dochodzi do świadomości samego podmiotu ten sąd wydającego. Sumienia

${ }^{14}$ Por. S. O l e j n i k, Przesłanki humanistyczne katolickiej doktryny moralnej, „Studia Theologica Varsaviensia”, 4(1966) f. 2, s. 167-186. Kwestię rzekomo dehumanizującego charakteru etyki katolickiej ks. Olejnik podjął już wcześniej w studium pt. Znamiona humanistyczne etyki katolickiej, „Collectanea Theologica”, 26(1955) f. 2, s. 207-249 oraz w artykule pt. Czy etyka bez Boga? „Ateneum Kapłańskie”, 54(1957), s. 218-235. Powrócił do niej znowu w artykułach: Etyka chrześcijańska a humanizm ateistyczny. Perspektywy dialogu, „Ateneum Kapłańskie”, 80(1973), s. 221-238 oraz Znaczenie kulturotwórcze moralności chrześcijańskiej, „Ateneum Kapłańskie”, 102(1984), s. 433-442. 
nie można więc uznać za ostateczną miarę dobra i zła moralnego. Jest to jednak miara bezpośrednio miarodajna. Należy słuchać głosu własnego sumienia, kontrolując go i w miarę potrzeby korygując"15.

Przy tej okazji ks. Olejnik przypomina nauczanie Kościoła na temat wolności sumienia, które stanowi niewątpliwie płaszczyznę spotkania z wszystkimi ludźmi dobrej woli. „Trzeba również szanować sumienie innych ludzi, nigdy nie posuwając się do jego brutalnego łamania, w razie potrzeby tylko, w miarę oczywiście możliwości, korygując jego ewentualny błąd lub błąd ten, jeśli tego żądają wymagania życia społecznego, tolerując. W sprawach sumienia etyka katolicka uczulenie na prawdę zespala z miłością do człowieka i szacunkiem dla jego wolności i godności"16. Wprawdzie ks. Profesor nie powołuje się wprost na dokumenty Soboru Watykańskiego II, ale w jego tekście nie trudno zauważyć obecność myśli soborowej ${ }^{17}$. Warto podkreślić aktualność refleksji dotyczącej humanistycznych znamion moralnego nauczania Kościoła, m.in. w odniesieniu do sumienia, jego autentycznej wolności oraz wpisanej w naturę człowieka możliwości błędu. W zmieniającym się kontekście kulturowym kwestie te - jako elementy dyskursu etycznego - pozostają niezmiennie ważne, na co szczególną uwagę zwrócił św. Jan Paweł II w encyklice Veritatis splendor ${ }^{18}$.

Na koniec krótkiego przeglądu zagadnień, w ramach których pojawił się temat sumienia, należy wspomnieć o polemice ks. Olejnika z autorami, którzy w opozycji do etyki chrześcijańskiej próbowali tworzyć etykę świecką, socjalistyczną lub niezależną. Autor tej ostatniej propozycji, prof. Tadeusz Kotarbiński, który w książeczce pt. Sprawy sumienia ${ }^{19}$ sformułował podstawowe założenia swojego systemu etyki oderwanego od religii, wskazał m.in., że namysł nad

15 S. O lej n i k, Przestanki humanistyczne katolickiej doktryny moralnej, art. cyt., s. 187.

16 Tamże, s. 187-188.

17 Por. KDK, nr 16, DWR, nr 3.

18 Por. J a n P a w e ł II, Encyklika Veritatis splendor, nr 32, 54-64.

19 Warszawa 1956 (wydana w ramach serii Biblioteczka Po Prostu). 
treścią głosu sumienia pozwala odkryć to, co zasługuje na szacunek, a co na pogardę. Odnosząc się do całej refleksji Kotarbińskiego nad sumieniem, ks. Profesor zarzuca jej najpierw uproszczenie, które nie docenia powszechności tego zjawiska oraz bogactwa opisów, świadectw i myśli obecnych w literaturze i filozofii już od czasów starożytnych. Przy okazji zwięźle przypomina istotne funkcje sumienia, które „oświeca i świadczy, wskazuje i zobowiązuje, oskarża i broni, sądzi i karze człowieka - w tej płaszczyźnie, którą nazywamy moralnością. Jest to więc jakiś wewnętrzny trybunał. Jego głos narzuca się człowiekowi z siłą imperatywu, jako dyrektywa osobiście wiążąca. Dokładnie zaś sumienie jest pewną szczególną własnością czy funkcją ludzkiej osobowości, w której dochodzą do uświadomienia osobiście zobowiązujące wymagania moralności" ${ }^{20}$. Podkreśla przy tym, że tak opisanego zjawiska sumienia, jego trwałości i powszechności, jego zasadniczej niezmienności i imperatywności, nie wyjaśnią ,ani czynniki dziedziczne, ani wpływy życia społecznego, ani umowy społeczne, ani antagonizmy klasowe. Trzeba sięgnąć głębiej: do obiektywnego, narzucającego się człowiekowi porządku wartości, a poprzez niego dojrzeć ostateczne źródło tego porządku: Boga"21.

\section{PODRECZNIKOWE UJECIA SUMIENIA}

Całościowe spojrzenie na rzeczywistość ludzkiego sumienia zawierają kolejne wersje posoborowego podręcznika do teologii moralnej ${ }^{22}$. Rozdział poświęcony sumieniu przedstawia trzy główne zagadnienia: zjawisko sumienia i jego teologiczną interpretację, normatywność sumienia oraz wychowanie sumienia. Punktem wyjścia jest powszechność doświadczenia zjawiska sumienia, którego

20 S. O le j n i k, Czy etyka bez Boga?, „Ateneum Kapłańskie”, 54(1957), s. 235.

21 Tamże.

22 S. Ole j n i k, Wodpowiedzi na dar i powołanie Boże. Zarys teologii moralnej, Warszawa 1979; Tenże, Dar - Wezwanie - Odpowiedź. Teologia moralna, t. 1-7, Warszawa 1988-1993; Tenże, Teologia moralna fundamentalna, Włocławek 1998; Tenże, Teologia moralna życia osobistego, Włocławek 1999; Tenże, Teologia moralna życia społecznego, Włocławek 2000. 
złożoną treść wielorako opisuje język potoczny, filozofia i literatura, od starożytnej po współczesną. Ks. Olejnik wskazuje na starożytnych autorów greckich i rzymskich ${ }^{23}$ i krótko zwraca uwagę na teksty biblijne potwierdzające powszechny, ogólnoludzki charakter zjawiska sumienia. W kolejnym artykule przedstawia teologiczną refleksję nad sumieniem, w której powraca do przekazu biblijnego, tym razem skupiając się na wypowiedziach św. Pawła ${ }^{24}$.

$\mathrm{Na}$ tak zarysowanym tle ks. Profesor krótko ukazał etapy rozwoju teologii sumienia. Wspomniał o ojcach Kościoła i zatrzymał się przy św. Tomaszu i jego poprzednikach ze szkoły franciszkańskiej i dominikańskiej, którzy odróżniali synterezę od sumienia i omawiali ich istotę. Następnie zwrócił uwagę na odejście od intelektualistycznej orientacji w wyjaśnianiu sumienia za sprawą fenomenologii i psychologii, które poważnie wpłynęły na dwudziestowieczną teologię. Dzięki ich zdobyczom sumienie przedstawia się dzisiaj całościowo, widząc w nim udział wszystkich czynników psychicznych, a więc nie tylko rozumu, ale także sfer wolitywnej i emocjonalnej ${ }^{25}$.

W tym kontekście ks. Olejnik podkreśla, że dowartościowując płaszczyznę socjologiczną i psychologiczną refleksji (wpływ środowiska, obyczajów i wychowania), należy odwołać się do danych antropologii, aby zrozumieć imperatywny charakter sumienia. Ostatecznie genezy głosu sumienia i jego autorytatywnego charakteru

${ }^{23}$ Czyni tak od drugiej wersji podręcznika, natomiast w pierwszej wskazanie to włączone jest w prezentację rozwoju historycznego nauki o sumieniu. Por. S. O l e j n i k, Wodpowiedzi na dar i powołanie Boże, dz. cyt., s. 196; Tenże, DarWezwanie-Odpowiedź, t. 3, dz. cyt., s. 91.

${ }^{24}$ Świadectwa biblijne zostały rozdzielone na dwa artykuły, co wydaje się nieco sztucznie, gdyż w całości stanowią one fundament dla dalszej refleksji teologicznej. Takiego rozdziału nie zawierały dwie poprzednie wersje podręcznika, w których występował wyraźny podział na teksty Starego i Nowego Testamentu. Por. S. O le j n i k, Teologia moralna fundamentalna, dz. cyt., s. 233-238; Tenże, Wodpowiedzi na dar i powołanie Boże, dz. cyt., s. 190-195; Tenże, Dar-Wezwanie-Odpowiedź, t. 3, dz. cyt., s. 82-89.

25 Por. S. Ole j n i k, Teologia moralna fundamentalna, dz. cyt., s. 238-240; Tenże, W odpowiedzi na dar i powołanie Boże, dz. cyt., s. 195-198; Tenże, DarWezwanie-Odpowiedź, t. 3, dz. cyt., s. 91-94. 
trzeba upatrywać w Bogu i w Jego powołaniu, które kieruje On indywidualnie do każdego człowieka. Ten religijnomoralny charakter sumienia przypomniał Sobór Watykański II w znanym tekście konstytucji duszpasterskiej Gaudium et spes, nr 16. W sumieniu człowiek staje wobec Boga, toczy z Nim dialog rozpoznając prawo, które wypełnia się w miłości do Niego i do bliźnich. Boże działanie w sercu człowieka jest ostatecznie tajemnicą, ma charakter ukryty i zazwyczaj posługuje się pośrednictwem przyczyn drugorzędnych. Dlatego nie należy w każdym odruchu sumienia widzieć cudownego działania czy interwencji Boga ${ }^{26}$.

Ukazując kwestię normatywności sumienia ks. Profesor omawia najpierw pewność i prawość, jako warunki pozwalające zaufać głosowi sumienia ${ }^{27}$. Ponieważ nie godzi się działać w stanie wątpliwości sumienia, dlatego należy dążyć do wyrobienia sobie pewnego sądu. Natomiast ze względu na możliwość popełnienia błędu istnieje potrzeba kontroli głosu sumienia, korzystania z pomocy Kościoła, któremu zostało powierzone Prawo Boże. Należy czynić to w duchu wolności, zwracając jednocześnie uwagę na czynniki o charakterze psychologicznym, które utrudniają kontrolę i osiągnięcie stanu prawości sumienia. Są nimi lekkomyślność, nierozsądek i niedbałość. Ponadto istnieją stany wypaczonego sumienia, jego nieczułości czy niewrażliwości, które niekiedy są efektem chorób psychicznych, ale najczęściej związane są z przyzwyczajeniem. Gdy człowiek często powtarza pewne występki, tak się z nimi oswaja, że z ich powodu nie odczuwa już ostrzeżeń czy wyrzutów. Obok nieczułości problemem jest sumienie faryzejskie, skrupulackie czy powikłane. Na ich tle

26 Por. Tenże, Teologia moralna fundamentalna, dz. cyt., s. 240-243; Tenże, Wodpowiedzi na dar i powołanie Boże, dz. cyt., s. 198-200; Tenże, Dar-Wezwanie-Odpowiedź, t. 3, dz. cyt., s. 94-99.

27 Tylko w pierwszej wersji Autor krótko opisał sytuacjonizm etyczny i przedstawił elementy krytyki tego nurtu w odniesieniu do tematu sumienia. Natomiast w wersji drugiej wspomniał o tym na początku paragrafu poświęconego wychowaniu sumienia. Por. S. O l e j n i k, Wodpowiedzi na dar i powołanie Boże, dz. cyt., s. 201-203; Tenże, Dar - Wezwanie - Odpowiedź, t. 3, dz. cyt., s. 125-126; Tenże, Teologia moralna fundamentalna, dz. cyt., s. 255-256. 
rysuje się treść sumienia zdrowego, które charakteryzuje spokojna i czujna gotowość, delikatność i wrażliwość, uwzględnianie i porządkowanie spraw i obowiązków według rzeczywistej hierarchii wartości, wreszcie pewność i zdecydowanie. Wyrobienie tych właśnie przymiotów jest celem wychowania sumienia ${ }^{28}$.

W paragrafie poświęconym temu zagadnieniu ks. Olejnik wskazuje najpierw, że - obok wcześniej wymienionych cech - chodzi o ukształtowanie sumienia ,światłego i dojrzałego, aby mogło być ono niezawodnym źródłem właściwej oceny i normy moralnej" 29 . Wyjaśnia pojęcie sumienia „oświeconego” przez wskazanie na roztropnościowy wymiar sumienia i omawia jego poszczególne wyznaczniki: zdrowy rozsądek, znajomość życia, trafna ocena sytuacji oraz zdolność patrzenia w przyszłość. Następnie ukazuje czynnik religijny w wychowaniu sumienia, którego elementami są klimat miłości Bożej jako warunek osiągnięcia dojrzałości moralnej, modlitwa i życie sakramentalne. Podkreśla szczególnie udział w Eucharystii i niezastąpioną rolę sakramentu pokuty i pojednania $\mathrm{w}$ formowaniu sumienia czułego (delikatnego). Na koniec ukazuje wychowanie sumienia jako proces, na który składają się cztery etapy: anomii, heteronomii, socjonomii i autonomii. Korzystając z wiedzy psychologii rozwojowej charakteryzuje te fazy i omawia czynniki służące personalizacji sumienia, czyli przeobrażenia go ze struktury heteronomicznej w autonomiczną ${ }^{30}$. Podsumowując znaczenie różnych działań natury wychowawczej, ks. Olejnik stwierdza: „Potęga łaski jest nie do przecenienia. Potrafi ona uzupełnić braki i przekreślić

28 Por. Tenże, Teologia moralna fundamentalna, dz. cyt., s. 244-254; Tenże, Wodpowiedzi na dar i powołanie Boże, dz. cyt., s. 203-212; Tenże, Dar-Wezwanie-Odpowiedź, t. 3, dz. cyt., s. 100-124.

29 Tenże, Teologia moralna fundamentalna, dz. cyt., s. 254.

30 Por. tamże, s. 255-268. W drugiej wersji podręcznika Autor najpierw omówił psychologiczno-pedagogiczne uwarunkowania procesu wychowania sumienia, a dopiero po nich wskazał na czynnik religijny w formacji sumienia. Por. S. O l e j n i k, Dar-Wezwanie - Odpowiedź, t. 3, dz. cyt., s. 127-138. 
błędy w kształtowaniu sumienia. Jej działanie jednak wymyka się analizie psychologów i pedagogów"31.

Warto zauważyć, że omówiony rozdział podręcznika poświęcony sumieniu wskazuje na szczególny rys twórczości ks. prof. Olejnika. Mając bowiem na względzie czytelnika i jego potrzeby w zmieniającej się rzeczywistości, nie zadowalał się ponownym wydaniem raz przygotowanego tekstu. Uzupełniał go i modyfikował w kolejnych wersjach podręcznika. Zmieniając nieco układ prezentowanych treści, ciągle szukał dla nich najlepszego miejsca w całości wykładu. Duży akcent położył na wskazania dotyczące formowania sumienia, pokazując w ten sposób, że refleksja teologicznomoralna ma wymiar praktyczny i służy duszpasterstwu. Wśród ważnych uzupełnień, które pojawiły się w drugiej i trzeciej wersji podręcznika wymienić należy wyraźne podkreślenie znaczenia integralnej antropologii dla wyjaśnienia zjawiska sumienia, a w szczególności jego imperatywnego charakteru. Natomiast pewnym mankamentem podręcznika, którego ostatnia wersja ukazała się pięć lat po publikacji encykliki Veritatis splendor, jest brak odniesień czy też śladów recepcji tego papieskiego dokumentu w kwestii sumienia.

\section{SUMIENIE W RAMACH REFLEKSJI NAD ETYKĄ LEKARSKĄ}

Przykładem aplikacji całościowego spojrzenia na sumienie jest zagadnienie etyki lekarskiej. W dorobku ks. profesora Olejnika znaleźć można propozycję dwóch ujęć, z których jedno podkreśla specyfikę chrześcijańskiego podejścia do wykonywania zawodu, a drugie bardziej uniwersalne - jedynie sygnalizuje tę specyfikę. Przed ich omówieniem warto wskazać na artykuł podejmujący dyskusję wokół normatywnego charakteru etyki zawodowej, w szczególności wokół tzw. kodeksów etyki zawodowej. Jak zauważa ks. Profesor, wartość takich kodeksów bywa kwestionowana w imię rzekomo zagrożonej autonomii sumienia. Ich odrzucanie uzasadnia się potrzebą

31 Tenże, Teologia moralna fundamentalna, dz. cyt., s. 268. 
zachowania autentyzmu decyzji sumienia, osobistego zaangażowania moralnego lub interioryzacji wartości moralnych ${ }^{32}$. Spośród tych trzech spraw właściwe rozumienie autonomii sumienia jest zagadnieniem szczególnie podkreślanym w obu ukazanych niżej ujęciach.

Pierwsze ujęcie, akcentujące znaczenie wiary w refleksji nad etyką lekarską, osadzone jest w kontekście dynamicznego rozwoju medycyny oraz możliwości ingerowania w początek i rozwój życia ludzkiego. Ks. Olejnik zwraca uwagę, że słuszną autonomię medycyny w zakresie wiedzy i sztuki zawodowej, łatwo przenosi się na obszar ocen etycznych wszystkich działań podejmowanych przez lekarzy oraz rozstrzygnięć problemów moralnych pojawiających się w związku z ich pracą. „Najdalej posunięty postulat autonomii sprowadza wszystkie te sprawy do oceny i decyzji sumienia"33. Odnosząc się do niego potwierdza potrzebę odwoływania się do sumienia lekarza, szczególnie w sprawach jego praktyki, które dotyczą poważnych dóbr pacjentów lub jego samego. Należy więc szanować prawo do wolności sumienia i w tym sensie - jak to przedstawiał ks. Profesor przy innych okazjach - można mówić o jego autonomii, która jednak nie ma charakteru absolutnego. Choćby ze względu na trudności z oceną niekiedy bardzo skomplikowanych przypadków, w których indywidualny osąd moralny wspierają i umożliwiają rozwiązania ukształtowane w ramach etosu grupy zawodowej. Ten natomiast odwołuje się do ogólnoludzkiego zmysłu moralnego, który w kulturze chrześcijańskiej został wzbogacony o prawo moralne przyniesione przez Chrystusa ${ }^{34}$.

W tym miejscu pojawia się ważna i ciągle aktualna potrzeba integracji w zakresie oceny moralnej, tak by uniknąć swoistej dychotomii - wyodrębnienia w świadomości lekarza osądu sumienia lekarskiego od osadu sumienia ludzkiego czy chrześcijańskiego. Zwrócenie uwagi na takie niebezpieczeństwo nabiera znaczenia

32 Tenże, Chrześcijańska etyka pracy zawodowej. Ewolucja problematyki, „Śląskie Studia Historyczno-Teologiczne” 6 (1973), s. 57.

33 Tenże, W kręgu moralności chrześcijańskiej, Warszawa 1985, s. 252.

34 Por. tamże, s. 253. 
w obliczu żądań, by swój światopogląd i swoje sumienie zostawić w domu, a zawód lekarza wykonywać niejako w oderwaniu od niego, co w istocie jest zamachem na prawo do wolności sumienia. Współczesnymi, spektakularnymi przykładami takiego niebezpieczeństwa były w 2014 roku zdumiewająco negatywne reakcje na Deklaracje wiary lekarzy katolickich i kazus prof. Bogdana Chazana, ginekologa położnika, którego oskarżano i publicznie potępiano, a ostatecznie zwolniono z pracy za odmowę aborcji dziecka z głębokimi wadami rozwojowymi ${ }^{35}$. Niestety, problemy z egzekwowaniem klauzuli sumienia mają charakter powszechny ${ }^{36}$.

Wśród innych spraw stanowiących kontekst dla osądów sumienia lekarskiego jest niepokojące przesunięcie w zakresie zadań, które stoją przed medycyną. Zdaniem niektórych lekarzy, chodzi w niej już nie tylko o leczenie człowieka, ale o możliwości ingerowania, a nawet projektowania człowieka i jego środowiska. Zmianie ulega także wzorzec lekarza, którego cechuje pewność siebie, odwaga badawcza, świadomość potężnej władzy nad życiem i śmiercią człowieka ${ }^{37}$. Podstawowym kryterium oceny moralnej działań podejmowanych w medycynie staje się postęp. Ma on rzekomo usprawiedliwiać różnego rodzaju badania i eksperymenty, które budzą wątpliwości etyczne, niepokój, a niekiedy wprost oburzenie. Jednak właśnie w imię postępu zaczyna zwyciężać podejście utylitarne i towarzysząca mu zasada, że cel uświęca środki. Jednym z przejawów takiego podejścia są ujawniane co jakiś czas eksperymenty medyczne prowadzone za cenę

35 W punkcie 4. Deklaracji zapisano: „Stwierdzam, że podstawą godności i wolności lekarza katolika jest wyłącznie jego sumienie oświecone Duchem Świętym i nauką Kościoła i ma on prawo działania zgodnie ze swoim sumieniem i etyką lekarską, która uwzględnia prawo sprzeciwu wobec działań niezgodnych z sumieniem" (http://www.deklaracja-wiary.pl/); Por. Prawo do życia. Bez kompromisu. Z prof. Bogdanem Chazanem rozmawia Maciej Müller, Kraków 2014.

${ }^{36} \mathrm{Na}$ ten temat dyskutowano m.in. podczas międzynarodowej naukowej konferencji prawniczej 5.09.2015 w Warszawie. Por. Trudności przy korzystaniu z klauzuli sumienia, http://www.naszdziennik.pl/polska-kraj/143331,trudnosci-przy-korzystaniu-z-klauzuli-sumienia.html (7.09.2015).

37 Por. S. Ole j n i k, W kręgu moralności chrześcijańskiej, dz. cyt., s. 255. 
zdrowia, a nawet życia ludzi sprowadzonych do poziomu królików doświadczalnych ${ }^{38}$.

Dlatego w ocenie konkretnych działań medycznych trzeba odwoływać się do integralnej antropologii, która uwzględniając także dane objawione ukazuje godność i uzasadnia prawa osoby ludzkiej. W świetle prawdy o człowieku, najpełniej objawionej w osobie Jezusa Chrystusa, można dokonywać osądów sumienia i uzgadniać swoje postępowanie z obiektywnym porządkiem moralnym. Chrześcijańska wizja sumienia, którą przypomniał Sobór Watykański II, zachowując swoją specyfikę staje się jednocześnie propozycją uniwersalną. Wskazuje bowiem na miłość jako sposób odnoszenia się do drugiego człowieka, w której wypełniają się wszystkie nakazy prawa Bożego (por. Mt 22, 35-40; Ga 5, 14; 1 Tm 1,5). Sumienie bowiem jako bezpośrednia norma moralności wskazuje na tę najwyższą i ostateczną normę ludzkiego postępowania. Natomiast rola Kościoła i jego wypowiedzi dotyczących zagadnień etyki lekarskiej polega na wspieraniu osądu sumienia refleksją w świetle Ewangelii i naturalnego prawa moralnego ${ }^{39}$.

Drugie ujęcie etyki lekarskiej, jak zapewnia czytelników ks. Olejnik, „,nie ma charakteru konfesyjnego, lecz całkowicie humanistyczny. Jej treść jest niezależna od religii. Stanowi wynik myślenia, pogłębionej refleksji nad istotą powołania i specyfiką zadań lekarza"40. $\mathrm{W}$ jej ramach zagadnienie sumienia pojawia się po gruntownym uzasadnieniu potrzeby etyki w medycynie (po ukazaniu m.in. bezdroży amoralizmu i konieczności przezwyciężenia subiektywizmu moralnego). Jej praktycznym wyrazem będzie właśnie odwoływanie się przez lekarzy do własnego sumienia, by rozwiązywać problemy moralne pojawiające się w pracy zawodowej. Ks. Profesor wskazuje

38 Ks. Olejnik odwołuje się do przykładów eksperymentów medycznych głośnych w latach 60-tych i 70-tych XX wieku. Dowodzą one, że takie niegodne człowieka podejście nie zakończyło się wraz z osądzeniem niemieckich lekarzy, którzy na masową skalę eksperymentowali w obozach zagłady podczas II wojny światowej.

Por. S. O le j n i k, W kręgu moralności chrześcijańskiej, dz. cyt., s. 256-257.

39 Por. tamże, s. 258-264; KDK, 16; DWR, nr 3.

40 S. Olej n i k, Etyka lekarska, wyd. 2, Katowice 1995, s. 6. 
na powszechny charakter zjawiska sumienia, które każdemu człowiekowi pozwala dostrzec, co w jego działaniu jest dobre, a co złe, a także nakazuje, co powinien czynić, a czego unikać. „Jest to dar natury, wtórnie ukształtowany przez kulturę. Z nim się człowiek rodzi, podobnie jak rodzi się ze zdolnością myślenia, czy też odczuwania wstydu lub współczucia dla cierpiących"41.

Wymieniając funkcje, które spełnia sumienie, ks. Olejnik wskazuje na moralną ocenę działania, na ostrzeżenie lub zachętę, nakaz lub zakaz oraz na wyrzuty, które czyni. Podkreśla przy tym, że jest to przeżycie duchowe złożone, w którym czynnik intelektualny łączy się z emocjonalnym. Lekarz ma prawo i powinien postępować zgodnie ze swoim sumieniem, troszcząc się by jego głos był pewny i jednoznaczny. Cechą dobrze uformowanego sumienia jest także prawdziwość, czułość, delikatność i wrażliwość. Tak jak w poprzednim ujęciu, zwraca uwagę, że sumienie nie może być tratowane jako ostateczna norma moralności, lecz potrzebuje obiektywnego punktu odniesienia. Wskazuje na niebezpieczeństwa sytuacjonizmu, w którym sumienie przejawia swego rodzaju podatność na zmianę - ten sam rodzaj działania ocenia dobrze lub źle w zależności od sytuacji, nie licząc się z obiektywnymi wskazaniami i zasadami etyki ${ }^{42}$.

Ze względu na możliwość błędu w trudnych sytuacjach czy przypadkach wątpliwych trzeba odwoływać się do rady innych, ale nade wszystko do wielowiekowej powszechnej tradycji etycznej w medycynie, wypracowanych kodeksów etyki lekarskiej, ale także licznych świadectw życia polskich lekarzy-myślicieli łączących wysoki poziom zawodowy i moralny. Podkreślając humanistyczny, autentycznie ludzki charakter etyki lekarskiej, zasadniczo zgodny z ujęciem chrześcijańskim, ks. Profesor zwraca na koniec uwagę na religijną interpretację sumienia, ukazaną w wymienianych już dokumentach Kościoła i jego służebną rolę w odniesieniu do sumień lekarzy. Obok

\footnotetext{
41 Tamże, s. 38.

42 Tamże, s. 38-40.
} 
głoszenia Ewangelii wskazuje on także na osobowe wzory postępowania, dołączając do grona świętych również lekarzy ${ }^{43}$.

Podsumowując przegląd problematyki sumienia w publikacjach ks. prof. Stanisława Olejnika warto podkreślić, że zajmowała ona ważne miejsce w całej jego twórczości naukowej. Temat sumienia przewijał się w niej w różnej formie, zawsze jednak objawiając swoje fundamentalne znaczenie w życiu moralnym człowieka. Dlatego ks. Profesor nie tylko przypominał bardzo bogatą, wielowiekową tradycję refleksji nad sumieniem, ale także poznawał, krytycznie oceniał i wykorzystywał ujęcia współczesne. Odważnie zabierał głos i polemizował z poglądami błędnymi, a nawet wrogimi chrześcijańskiej wizji człowieka i jego sumienia. Nade wszystko jednak cierpliwie ukazywał i wyjaśniał stanowisko etyki katolickiej. W trosce o swoich czytelników nieustannie dopracowywał całościowe religijnomoralne ujęcie tematu sumienia. Często odwoływał się i pozostawał wierny nauczaniu Kościoła, ale ze względu na powszechność zjawiska sumienia, proponował także uniwersalne, autentycznie humanistyczne spojrzenie, które przedstawiał m.in. w ramach refleksji nad etyką lekarską. W ten sposób ks. prof. Olejnik pozostawił wieloaspektowe opracowanie tematu sumienia, do którego warto wracać.

\section{Streszczenie}

Problematyka sumienia zajmowała ważne miejsce w twórczości naukowej ks. prof. Stanisława Olejnika. Pojawiła się już w pierwszych jego publikacjach i pozostała ciągle powracającym przedmiotem refleksji. Artykuł przypomina dokonania na tym polu zwracając uwagę że ks. prof. Olejnik czerpał zarówno z bogatej tradycji refleksji nad sumieniem, jak i poznawał, krytycznie oceniał i wykorzystywał ujęcia współczesne. Odważnie polemizował z poglądami błędnymi, a nawet wrogimi chrześcijańskiej wizji człowieka i jego sumienia. Nade wszystko cierpliwie wyjaśniał stanowisko etyki katolickiej. W trosce o czytelników nieustannie dopracowywał całościowe religijnomoralne ujęcie tematu sumienia. Odwoływał się do

\footnotetext{
43 Tamże, s. 41-50.
} 
nauczania Kościoła, ale proponował także uniwersalne, humanistyczne spojrzenie, które przedstawił m.in. w ramach refleksji nad etyką lekarską.

\section{The Issues of Conscience in Selected Publications of Fr. Prof. Stanislaus Olejnik Summary}

The issues of conscience played an important role in the scientific creativity of Father. prof. Stanislaus Olejnik. These aspects were already present in his first publications and remained a constantly recurring subject of reflection. The article recalls his achievements in this field, noting that Fr. prof. Olejnik drew from both the rich tradition of reflection on the conscience and learned, critically assessed and used a contemporary approach. He boldly argued with views which were erroneous, and even hostile to the Christian vision of man and his conscience. Above all, he patiently explained the position of Catholic ethics. Bearing in mind the interest of readers he constantly elaborated on the religious and moral holistic approach to the subject of conscience. He referred to the teaching of the Church, but also proposed a universal, humanistic outlook, which he introduced, among others, in the context of reflection on medical ethics.

\section{Bibliografia:}

Góralczyk P., Misja uczonego - ksiadz profesor Stanisław Olejnik, w: J. Bagrowicz $\mathrm{i}$ inni (red,), W stużbie Kościolowi i nauce. Księga jubileuszowa dedykowana Księdzu Profesorowi Stanisławowi Olejnikowi, Włocławek 1994, s. 20-27.

Góralczyk P., W stużbie prawdzie i miłości. Ksiądz Profesor Stanisław Olejnikteolog moralista, w: P. Góralczyk, J.A. Sobkowiak (red.), Przemoc i terror. Ksiązka dedykowana Księdzu Profesorowi Stanisławowi Olejnikowi w 80ta rocznice urodzin i 50ta rocznice pracy naukowej, Warszawa 2001, s. 17-29.

Graczyk M., Ksiadz profesor Stanisław Olejnikjako teolog, „Studia Włocławskie”, 3 (2000), s. 7-19.

Greniuk F., Dzieje ksztattowania się koncepcji sumienia, w: J. Nagórny, A. Derdziuk (red.), Człowiek - Sumienie - Wartości. Materiały z sympozjum KUL, 2-3 XII $1996 r$., Lublin 1997, s. 75-90. 
Greniuk F., Katolicka teologia moralna w poszukiwaniu własnej tożsamości, Lublin 1993.

Inlender B., Problematyka sumienia w publikacjach polskich, „Collectanea Theologica", 60(1990) nr 3, s. 135-164.

Jan Paweł II, Encyklika Veritatis splendor, Watykan 1993.

Kopciński J., Polska teologia moralna XX wieku, Kraków 2000.

Niedźwiecki M., Odnowa i rozwój polskiej teologii moralnej po Soborze Watykańskim II, Kraków 2002.

Olejnik S., Chrześcijańska etyka pracy zawodowej. Ewolucja problematyki, „Śląskie Studia Historyczno-Teologiczne”, 6(1973), s. 43-61.

Olejnik S., Czy etyka bez Boga? „Ateneum Kapłańskie”, 54(1957), s. 218-235.

Olejnik S., Dar - Wezwanie - Odpowiedź. Teologia moralna, t. 1-7, Warszawa 1988-1993.

Olejnik S., Encyklika Veritatis splendor o misji i posłudze teologów moralistów w Kościele, w: E. Janiak (red.), W prawdzie ku wolności. W kręgu encykliki Veritatis splendor, Wrocław 1994, s. 198-207.

Olejnik S., Etyka chrześcijańska a humanizm ateistyczny. Perspektywy dialogu, „Ateneum Kapłańskie”, 80(1973), s. 221-238.

Olejnik S., Etyka lekarska, wyd. 2, Katowice 1995.

Olejnik S., Ostatnie pótwiecze katolickiej myśli etycznej w Polsce, „Ateneum Kapłańskie", 58(1959) z. 1-3, s. 105-146.

Olejnik S., Problem ostatecznego kryterium dobra w moralności chrześcijańskiej, w: B. Bejze (red.), O Bogu i o człowieku, t. 2: Problemy filozoficzne i teologiczne, Warszawa 1969, s. 175-191.

Olejnik S., Przesłanki humanistyczne katolickiej doktryny moralnej, „Studia Theologica Varsaviensia", 4(1966) f. 2, s. 167-186.

Olejnik S., Sumienie, „Ateneum Kapłańskie”, 51(1949) z. 4, s. 363-371.

Olejnik S., Teologia moralna fundamentalna, Włocławek 1998.

Olejnik S., Teologia moralna życia osobistego, Włocławek 1999.

Olejnik S., Teologia moralna życia społecznego, Włocławek 2000.

Olejnik S., Veritatis splendor - encyklika Jana Pawta II o podstawach moralności chrześcijańskiej, „Ateneum Kapłańskie”, 122(1994) z. 2, s. 332-343.

Olejnik S., W kręgu moralności chrześcijańskiej, Warszawa 1985.

Olejnik S., W odpowiedzi na dar i powołanie Boże. Zarys teologii moralnej, Warszawa 1979.

Olejnik S., Z problematyki odpowiedzialności moralnej, „Ateneum Kapłańskie”, 50(1949) z. 3, s. 260-268. 
Olejnik S., Znaczenie kulturotwórcze moralności chrześcijańskiej, „Ateneum Kapłańskie", 102(1984), s. 433-442.

Olejnik S., Znamiona humanistyczne etyki katolickiej, „Collectanea Theologica”, 26(1955) f. 2, s. 207-249.

Prawo do życia. Bez kompromisu, z prof. Bogdanem Chazanem rozmawia Maciej Müller, Kraków 2014.

Reroń T., Drogi chrześcijańskiej moralności. Wkład ks. prof. Stanisława Olejnika w odnowe teologii moralnej, „Wrocławski Przegląd Teologiczny”, 15(2007) nr 2, s. 87-100.

Sobór Watykański II, Deklaracja o wolności religijnej Dignitatis humanae (7.12.1965).

Sobór Watykański II, Konstytucja duszpasterska o Kościele w świecie współczesnym Gaudium et spes (7.12.1965).

Trudności przy korzystaniu z klauzuli sumienia, http://www.naszdziennik.pl/polska-kraj/143331,trudnosci-przy-korzystaniu-z-klauzuli-sumienia.html (7.09.2015).

Wanat Z., Sumienie w blasku Prawdy. Polska teologia sumienia XX wieku, Toruń 2012.

Werbiński I., Spis publikacji naukowych ks. prof. dra hab. Stanisława Olejnika, w: J. Bagrowicz i inni, (red.), W stużbie Kościołowi i nauce. Księga jubileuszowa dedykowana Księdzu Profesorowi Stanisławowi Olejnikowi, Włocławek 1994, s. 34-37.

Wichrowicz J., Określenia sumienia w ostatnich publikacjach, „Collectanea Theologica", 52(1982) f. 2, s. 116-123. 